\title{
INFLUENCE OF SERVICE AND SATISFACTION TOWARDS CUSTOMER'S LOYALTY: A STUDY IN STATE-OWNED ISLAMIC BANK IN MAKASSAR, INDONESIA
}

\author{
Basalamah Muhammad Ridwan*, Moeljadi, Sunaryo, Sudjatno \\ Faculty of Economy and Business, University of Brawijaya, Indonesia \\ *E-mail: ridwanbasalamah19@gmail.com
}

\begin{abstract}
The number of Islamic bank in Makassar keeps increasing. The bank grows rapidly because of some competitive advantages it offers. In order to provide prime service for their customers, Islamic banks are supposed to improve their quality of service. Otherwise, customers may choose to save their money in other banks. Service quality is essential ijn order to survive business competition and maintain customer's loyalty. The purpose of the study is: 1) evaluate and analyze the influence of quality of service towards customer's loyalty and 2) evaluate and analyze the influence of satisfaction towards customer's loyalty. The setting of the study was 4 (four) Islamic banks in Makassar. The population was 200 state-owned Islamic bank customers in Makassar. The study was primary study. The data analysis method was SEM (Structural Equation Model). The findings showed that first, the quality of service had direct and non-significant influence towars customer loyalty and second, customer satisfaction has direct and significant influence towards customer loyalty.
\end{abstract}

\section{KEY WORDS}

Quality of service, satisfaction, customer loyalty.

Growth of banking industry and financial services has been significant for the last few years as the result of technological advances and deregulation. In the world of banking, Islamic banks is a relatively new type of service in banking industry that applies Syaria law in each of its activity. Due to tight competition in business that sells service, Islamic banks should understand the right strategy to win the competition.

Islamic banking has massive potentials since 1.2 billion of the populations are Moslem and their GDP is more than 1.3 billion US dollars (Skha Consulting, 2001). The countries with the highest Moslem populations are Indonesia, India, Pakistan and Bangladesh respectively. Furthermore, Kuwait has quite successful penetration of Islamic banks; the market share of Islamic banks in the country is approximately $30 \%$. The proportion of Islamic banks in Saudi Arabia is $12 \%$, that in Brunei is $11 \%$, in Malaysia is $5 \%$ while the national market share of Islamic bank is $1 \%$. Customer loyalty is the end-goal of banking industry. Satisfied customers will not be hsesitant to give positive testimony about banking products they use. Such testimonies have high credibility as loyal customers do not receive anything by making recommendation about banking service or banks they use.

It is no doubt that customer loyalty is pivotal in banking industries. Banks make serious effort to maintain long-term and/or lasting customers. Darsono (2004) explained that satisfied customers are still using products from competitors. In addition, Grifin (2005) showed that repetitive purchase that represents loyalty behaviour will develop customer retention.

Customer satisfaction goes hand-in-hand with customer loyalty. It is very likely that royal customers will become word of mouth advertisers, but there is huge chance they are loyal to certain banking products and service (Tjiptono, 2005:386). Oliver (1997) stated that loyalty is strong commitment and encourage repeated purchase. Customer loyalty means customer's commitment to keep using products or service of a bank.

To measure customer satisfaction, customer basically will compare quality of service they expect with the quality of service they receive. Comparison of both perceptions results in customer satisfaction and dissatisfaction. Based on the the previous elaboration, it can be concluded that service quality is the determining factor for customer satisfaction. When customer is satisfied with certain banking service, then it is highly likely that the customer will 
make transaction in the same bank repeatedly (Lupiyoadi, 2001: 231).

Makassar is selected as the setting of the study since until the end of December 2015 there have been 6 branches of Islamic banks (Mandiri and Muamalah) as well as and 9 Islamic business units (BRI, BNI, BTN and Andamon). In the development, Islamic bank strive on providing maximum service to its customers not only for ensuring customer satisfaction but also maintaining loyal customers.

One of the important factors of loyalty is satisfaction. Satisfied customers will make recommendation and ask other people to become customers of the bank in which they have saving account (Ilham, 2008). Based on Ilham (2008), Islamic bank's method to increase the number of customers had yet been effective. None of conventional bank customers was interested in moving their saving account to Islamic bank. There Hal ini disebabkan diantara respon yang telah menjadi nasabah bank konvensional tidak ada satupun yang berniat untuk memindahkan rekening mereka ke bank syariah. $26 \%$ of the respondents thought that bank interest is the same as usury and $27 \%$ of them admitted that they had very little idea about Islamic bank.

Based on the elaboration, the researchers think there is a need to conduct a study focusing on quality of service, satisfaction and loyalty of the Islamic ban customers in Makassar. It is expected that the findings become the means of evaluation and reference for Islamic banks to develop customer loyalty in order to maintain the existence of Islamic banks in Makassar.

\section{LITERATURE REVIEW}

Studies that analyzed causal relationship between quality of service and customer loyalty continuously had been frequently conducted such as Qawi (1999), Kandampully (1998), Lewis and Soureli (2006), Kasim and Abdullah (2010), and Liao-Hsi-Kun (2012) that showed positive, significant correlation between quality of service in improving customer loyalty; customer loyalty would increase when the quality of service met customer's expectation.

Selness (2003) conducted a study of which setting was 106 companies consisting of telephone and insurance company as well as university. It analyzed the influence of customer satisfaction towards loyalty; the finding was customer satisfaction had positive influence towards loyalty. Frimpong (2013) concluded that customer satisfaction and customer loyalty had become the focus of numerous studies such as Formell, et.al. (1996). Lewis and Soureli (2006) stated that important concept to take into account in developing customer loyalty was customer satisfaction. Satisfaction was measured by how well customer expectation was fulfilled. On the other hand, customer loyalty was overall indicator whether or not customer wanted to repurchase.

According to Kandampully (1998), customer loyalty was related to customer satisfaction. Customer was interested in banks that offered lower interest in loan or higher deposit rates. On the other hand, loyal customer decided to keep saving money in certain due to its prime service such as professional staffs, good communication and responsive staffs. Some methods to improve customer loyalty were giving accurate information on time such as one about the use and benefit of banking service.

Qualified service of Islamic banks resulting in satisfied customers represented how much care Islamic bank staffs had for their customers. Personal contact between customers and staffs was essential part of customer-company interaction; thus resource company had such as staff and technology should be utilized wisely so that customer loyalty could be maintained and developed (Taap, et.al., 2011). Kasim and Abdullah (2010) revealed that even customers who had expressed their satisfaction toward certain brand may use another brand and customer who did not express their satisfaction kept using the same brand. Bloemer, Josee, and Ko de Ruyter (1998) and Reichheld (1996) had the same idea that satisfaction had positive influence towards loyalty; however, it was important to highlight that increasing satisfaction did not always result in increasing loyalty, in the same degree (Reichheld, 1996). Therefore, the correlation between satisfaction and loyalty was not a 
linear one and as the consequence, satisfied customer may still shift to other brands (Amin, Isa, and Fontaine, 2011).

Conceptual Framework of the Study. The conceptual framework described the correlation between the variables in the study. The Relationship between the variables of the study was based on the theory of service quality, satisfaction, loyalty and previous research findings related to the relationship between service quality and satisfaction to customer loyalty. Based on the the correlation between the variables be it based on the theory or the previous studies, the conceptual framework of the study was formulated as seen from Fig. 1.

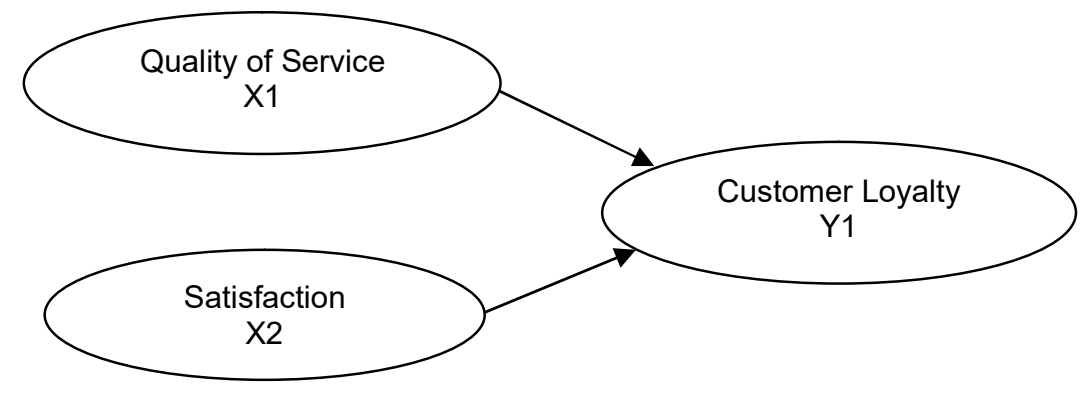

Figure 1 - Conceptual Framework

Hypothesis. According to Kandampully (1998), customer loyalty was associated to customer satisfaction. Customers would be attracted to competitors with lower rate on loan or higher interest on deposits. On the other hand, loyal customers preferred qualified service they had received such as professional staff, good communication and responsive staff. Customer loyalty could be developed by providing timely, trustworthy information, for example one about the use and benefits of banking services.

Satisfied customers/clients had positive attitude towards most of the aspects associated to Islamic banks. The banks had competitive advantage in gaining customer loyalty. In general, satisfied customers tend to make repeat purchases. It reflected strong loyalty towards Islamic banks (Taap, et. al., 2011).

When customers/ clients were satisfied with the services given by Islamic bank staffs (personal contact with the staffs), it meant the staffs cared about the customers. Contact between the staffs and customers become important part of customer and company interaction; therefore, company's resources such as staffs and technology should be utilized to maintain and enhance customer loyalty (Taap, et.al., 2011). It showed obvious gap and therefore, the first hypothesis of the study was:

H1. Service would improve customer loyalty. Satisfaction the customer got may increase their purchase intensity (Assael, 2007). Optimum level of customer satisfaction encouraged loyalty especially for satisfied customer. Customer loyalty was considered as the strength of the relationship between personal relative attitude and repeated business. It was vital since it was mediated by social norms and situational factors. In conclusion, customer loyalty was considered as the strength of the relationship between the individual relative attitude and repeated business.

The relationship between satisfaction and loyalty was different from what company had imagined. Jamal and Naser (2002) mentioned that the relationship between satisfaction and loyalty was unclear. Kasim and Abdullah (2010) revealed that a number of customers expressing satisfaction switched to other brands while dissatisfied customers did not. Bloemer, Josee, Ko de Ruyter (1998), Reichheld (1996) had similar idea that satisfaction had positive influence to loyalty, but increase in satisfaction did not always result in increasing loyalty, to the same degree (Reichheld, 1996). Therefore, the relationship between satisfaction and loyalty was not linear one so that satisfied customers were still able to switch brands (Amin, Isa, and Fontaine, 2011). Oliver, et. al., (1997) suggested that the relationship between customers and customer loyalty was non-linear. Anderson and Sullivan (1993) also stated that the relationship between customer satisfaction and loyalty was non-linear either. 
O'Mallaey (2008) highlighted that the relationship between satisfaction and loyalty was not linear and consequently, promotion as reward for loyal customers was dangerous. The danger was companies may be trapped in the circle of marketing and consumers would not find any reason to make repeat purchases. Loyalty was criticized because although customers were satisfied with the service got, they would keep shifting to other products/ service because they believed they would get better value, comfort and quality.

Other studies noted that customer satisfaction had positive influence on customer loyalty research for example a study conducted by Selness (2003) in 106 companies that consistied of the telephone company, insurance companies and university. Frimpong (2013) stated that customer satisfaction and customer loyalty had become the focus of some researchers such as Formell C, MD Johnson, et.al (1996). Lewis and Soureli (2006) stated that the important concept to be considered in designing loyalty program was customer satisfaction. Satisfaction was measured on how well customer expectations were met. Meanwhile, customer loyalty was the overall measurement whether or not customer wanted to make another purchase. Thus, the second hypothesis was:

H2. Satisfaction will increase customer loyalty.

\section{OPERATIONAL DEFINITION}

Service (X1). Quality of service is a condition that described customer's perception towards service performance by Islamic bank. The indicators of the service quality variable in the study were developed based on the ideas by Parasuraman et al., (1994), Abdul Qawi (1999), Othman and Owen (2001); it was is the first developed indicator for Islamic banking industry. Carter model was six-dimensional models developed based on SERVQUAL and a new dimension called in accordance to the Islamic law (Complience/ adherence to Sharia). Six indicators of CARTER were (Complience, Assurance, Reliability, Tangible, Empathy, and Responsiveness).

Satisfaction (X2). Customer satisfaction is a condition that describes customer's response toward evaluation of experience in using Islamic bank service satisfaction of Islamic banks in increasing customer loyalty. The customer satisfaction indicators were adapted based on the ideas proposed by Engel et. al. (1995) and Kotler (2003). The indicators were Experience and Overall Satisfaction.

Customer Loyalty (Y1). Customer loyalty was positive attitude of customers towards Islamic bank customers and commitment to keep being customers in the future. The indicators to measure customer loyalty were adapted from Dharmamesta (2001), Peter and Olson (2002) namely: repurchase or willingness to keep being customer of certain Islamic bank and increase number of banking transaction in Islamic bank; give information to other people in the form of recommendation or promote products of Islamic bank to other customers; become loyal customer of Islamic bank.

\section{RESEARCH METHODS}

The setting of the study was state-owned Islamic Banks that had Islamic Business Unit in Makassar (Mandiri Syari'ah, BNI Syari'ah, BRI Syariah, and BTN Syari'ah) for easy access to information. The subjects of the study were the customers of the state-owned Islamic Banks that had Islamic Business Unit in Makassar (Mandiri Syari'ah, BNI Syari'ah, BRI Syariah, and BTN Syari'ah). The study lasted for six months (June 2015 - December 2015). The data analysis method was SEM (Structural Equation Model) with AMOS program. (Ghozali, 2008:18) Such analysis was categorized as quantitative analysis.

\section{FINDINGS AND DISCUSSIONS}

Hypothesis 1: Increasing quality of service increased customer loyalty. The quality of service in the study adopted Parasuraman et al, (2002)'s idea of quality of service that had five dimensions. Parasuraman et al, (2002)'s idea was re-evaluated by Abdul Qowi (2009), 
and Othman and Lynn Owen (2001) who classified "servqual" into 6 dimensions called CARTER (Complience, Assurance, Reliability, Tangibles, Empathy, Responsiveness); CARTER was associated directly to customer loyalty. The loading factor of 0.126 and probability of 0.110 showed that the quality of service did not have significant influence towards the loyalty of the state-owned Islamic bank in Makassar's customers. The finding was at the opposite of the findings of the previous study conducted by Kazi Omar Siddiqi (2011), Hafeez Samraz and Muhammad Bakhtiar (2012) and Liao-Hsi-kun (2012).

Based on the analysis, the first hypothesis, increasing quality of service increased customer loyalty, was rejected or could not be accepted.

Hypothesis 2: Increasing satisfaction increased customer loyalty. The finding showed that satisfaction had positive and significant influence towards customer loyalty where the loading factor was 0.338 and probability was 0.021 . It meant the more satisfied the stateowned Islamic bank customers were, the more loyal they were. On the other hand, the less satisfied the state-owned Islamic bank customers were, the lower level of loyal they had to the banks. Based on the findings, the second hypothesis, increasing satisfaction of the stateowned Islamic bank in Makassar customers improved the level of the customer loyalty was accepted.

The finding was corroborated to the findings of Selness (2003)'s study in 106 companies consisted of universities, telephone and insurance companies. Frimpong (2013) described that customer satisfaction and customer loyalty had become the focus of numerous studies such as Formell (1996). Customer satisfaction was vital element to design loyalty program. Satisfaction was measured based on how well customer's expectation was fulfilled.

Limitation of the Study. The study was limited to 4 state-owned Islamic banks that had Islamic business unit in Makassar. The subjects were the customers of the four banks who had different chatacteristics to the customers of other Islamic banks in Makassar. As the result, the findings could not represent all or other Islamic banks in Makassar (could not be generalized).

\section{CONCLUSION AND SUGGESTIONS}

Based on the findings and discussion, the study can conclude the following points:

Quality of service is pivotal element of banking industry so that banks are able to carry out service quality that meets the expectation and perception of their customers. Based on the findings of the study, the quality of service in the state-owned Islamic banks in Makassar did not have direct influence towards the customer loyalty.

Customer satisfaction is a condition that explaines the customer's response towards their experience in using the service of the Islamic banks as well as satisfaction in improving the customer's loyalty. The customer satisfaction had direct influence towards the customer loyalty in the state-owned Islamic banks located in Makassar.

According to the conclusion, several suggestions can be made as follows:

The service quality of the state-owned Islamic banks in Makassar that have Islamic business units should be improved to maintain certain level of customer loyalty. The type of service that needs improvement is Syaria compliance.

Future researchers should expand the subjects of the study from one city to one province, for example taking several municipalities in South Sulawesi as subject. Future researchers may also analyze other variables such as fairness in the outcome or customer trust. It is expected that analyzing other variables will better represent the future need of Islamic bank.

\section{REFERENCES}

1. Amin, M., Isa, Z. and Fontaine, R. (2011). The role of customer satisfaction in enhancing customer loyalty in Malaysian Islamic banks. The Service Industries Journal, Vol. 31 No, pp. 1519-1532. 
2. Anderson, E.W. and Sullivan, M.W. (1993). The antecedents and consequences of customer satisfaction for firms. Marketing Science, Vol. 12, pp. 125-43

3. Bloemer, J., Ko de Ruyter and Peeters, P. (1998). Investigating driver of bank loyalty: the complex relationship between image, service quality and satisfaction. The international Journal of Bank Marketing. vol. 16, pp.276-292.

4. Engel F.J. et al (1995). Perilaku Konsumen. Penerbit Binapura Aksara Jakarta.

5. Formell C. et al (1996). The American Custumer Satisfaction Index: Nature, Purpose and Findings. Journal of Marketing. 60. October. pp. 7-17.

6. Frimpong, K. and Wilson, A. (2013). Relative importance of satisfaction dimension on service performance-a developing country context. Journal of service Management, Vol. 24 No. 4, pp.3-3.

7. Ghozali, I. (2008). Model Persamaan Struktural, Konsep and Aplikasi dengan AMOS 16.0. Semarang: Baand Penerbit Universitas Diponegoro.

8. Griffin, J. (2005) Costumer Loyalty: How to Earn it, How to Keep it. Lexington Book, 1230 Avenue of America, New York, USA

9. Jamal, A. and Naser, K. (2002). Customer satisfaction and retail banking: an assesment of some of the key antecedents of customer satisfaction in retail banking. International Journal of Bank Marketing, Vol. 20 No. 4, pp. 146-60

10. Kandampully, J. (1998). Service Quality to service loyalty: a relationship which goes beyond customer services. Total Quality Management and Business Excellence, 9(6), $431-443$.

11. Kasim, N. and Abdullah, N. (2010). The effect of perceived service dimension on customer satisfaction, trust, loyalty in e-commerce setting: a cross-cultural analysis. Asia Pacific Journal of Marketing and Logistic, Vol. 22 No. 3, pp. 351-371.

12. Kotler, P. (2003) Marketing Management: Analysis Planning Implementation, And Control, Eleventh Edition, Prentice Hall International, Inc. A. Devition of Simon and Scuser, Engelwood Cliffts.

13. Lewis, B.R. and Soureli, M. (2006). The antecedents of consumer loyalty in retail banking. Journal of Consumer Behaviour, Vol. 5 No. 1, pp. 15-31.

14. Liao-Hsi-Kun. (2012). Service Quality, and Customer Satisfaction: Direct and Indirect Effect in a B2B Customer Loyalty Framework. Journal of Global Business Management. Vol. 8, No.1, PP 86-93.

15. Lupiyoadi, R. (2001). Manajemen Pemasaran Jasa, Salemba Empat, Jakarta.

16. Oliver, R.L. (1997). Satisfaction A Behavioral Perspective on The Consumer. Mc GrawHill Companies, Inc, Singapore.

17. Othman A.Q. and Owen L. (2001). Adopting and measuring customer service quality (SQ) in Islamic Banks: A Case Study in Kuwait Finance House. International Journal of Financial Service, 3(1), 1-26.

18. Parasuraman, A., Valarie A.Z., and Berry, L.L. (1994) Reassesment of Expectation as a Comparison Standard in Measuring Service Quality: Implication for Further Research. Journal of Marketing, Vol.58 January, pp 111-124.

19. Qawi, A. (1999). Adopting and Measuring Customer Service Quality (SQ) in Islamic Banks: A Case Study in Kuawit Finance House. International Journal of Islamic Financial Service, Vol. 3, No.1.

20. Reichheld, F.F. (1996). The Loyalty Effect. Harvard Busniness School Press, Boston, MA.

21. Samraz, H. and Bakhtiar, M. (2012). The Impact of Service Quality, Customer Satisfaction and Loyalty Program on Customer Loyalty: Evidence from Banking Sector of Pakistan. International Journal of Business and Social Science. Vol.3, No.16, PP 200-209.

22. Siddiqi, K.O. (2011). Interrelations Between Service Quality Attributes. Customer Satisfaction and Customer Loyalty in the Retail Banking Sector in Bangladesh, 3(6):1236.

23. Taap, M.A. et al (2011). Measuring service quality of conventional and Islamic banks. International Journal of Quality and Reliability Management, 8(28):822-840.

24. Tjiptono, F. and Chandra, G. (2005). Service quality \& Satisfaction. Edisi Pertama, ANDI, Yogyakarta 